Volume 03 Number 02 Maret 2020

\title{
Analysis and dynamic behavior of portal structures due to reciprocating machine
}

\author{
Donald, ESSEN \\ Faculty of Engineering, Mercu Buana University, Jakarta, Indonesia \\ donaldessenstmt@gmail.com \\ Andreas, DWI PRATAMA \\ Faculty of Engineering, Mercu Buana University, Jakarta, Indonesia \\ andreasdwipratama@gmail.com
}

\begin{abstract}
reciprocating engine consists of two driving parts, piston and rotor, when the engine start these two parts move with a certain frequency, resulting in vibrations in the structure. dynamic analysis of the structure aim to find out how the structure behaves due to vibrations generated from the machine, whether the structure is safe for the machine and humans around the machine due to the amplitude of displacement, velocity, and displacement from structure. This dynamic analysis is carried out with the help of SAP 2000 v20.20 software with a dynamic load in the form of a reciprocating compressor operating with a frequency of $49.16 \mathrm{~Hz}$. In this final project, the machine foundation uses a table top type with $1 \times 1.7 \mathrm{~m}$ column dimensions and $1.3 \times 1.6 \mathrm{~m}$ beams. From the free vibration analysis, the result is a natural frequency structure, from the first ten modes the structure is declared safe from resonance However, in this study the displacement and velocity of structures that occur in the zone B \& $C$ while the acceleration into the safe category based on applicable standards. This means that the structure is safe for humans who are around but are not safe for the product and the machine itself if it operates for a long time continuously.
\end{abstract}

Keywords : Vibration, Dynamic Analysis, Frequency, Reciprocating Equipment Load, Machine Foundation

\section{INTRODUCTION}

Along with further expansion of the times and the economy then needs of industry on a country will also develop.At the moment, the industrial sector has contributed to national income of $20 \%$, then for taxation around $30 \%$, and exports until $74 \%$, of these achievements of the largest donated five manufacturing sector in indonesia ( bambang brodjonegoro, 2019 ). In the implementation of development the structure of the factory quite unique because consisting of the structure of the factory itself and also the structure to prop up a machine that operate.

The structure is different both static and dynamic received structure due to the movement of people in contrast to burden arising from the machines that are used to produce products if operating at a factory. On designing banguanan factory structure , structures are need to pay attention to increasing speed machines in vertical synchronization, the shake, the increase in torque, the horizontal, and combined of the displacements horizontally \& vertical (O'Neil,1979). Even need to consider the power of that structure when machine exploded to prevent very bad structure failure.

\section{METHODOLOGY}

The method used in this research is the method of literature study, this method is a study by looking for theoretical references in accordance with the case or problem found. References for this study were obtained from books, journals, research report articles, and sites on the internet. Structural modeling and analysis using SAP 2000 V.20 software to obtain natural frequency values, displacement amplitude, velocity amplitude, and acceleration amplitude of the portal structure. 
Figure 1. Research Flow Chart

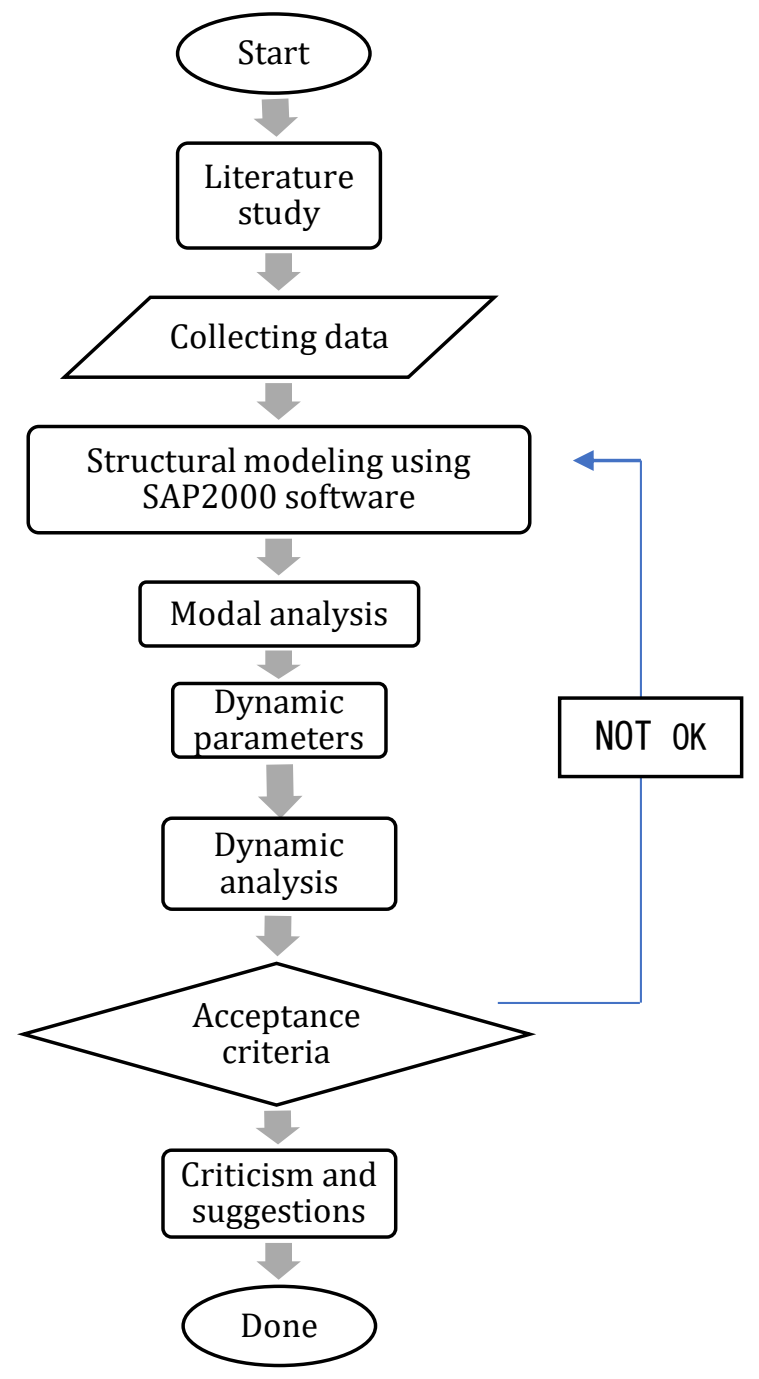

Source : Data in research, 2020

\subsection{Machine Data}

A machine that were analysed in this study is the engine compressor reciprocating with a total weight $56000 \mathrm{~kg}$. The dynamic force of the compressor engine from the moving part of the compressor and that part is used in calculating the amplitude of the vibration, displacement, speed, and acceleration.

Table 1. Data of Moving Components of Compressors

\begin{tabular}{lcccc}
\hline Description & $\begin{array}{c}\text { Rotor weight } \\
(\mathrm{kg})\end{array}$ & $\begin{array}{c}\text { Operating } \\
\text { frequency } \\
(\mathrm{rpm})\end{array}$ & $\begin{array}{c}\text { Dynamic load } \\
(\mathrm{kg})\end{array}$ & Torque (kgm) \\
\hline Main motor & 1500 & 2950 & 331 & 594 \\
compressor & 1350 & 2950 & 319 & 594 \\
\hline
\end{tabular}

Source : Data in research, 2020

Figure 2. Location and Compressor Machine Parts, a) Load Point, b) Side View Machine Parts 
Volume 03 Number 02 Maret 2020

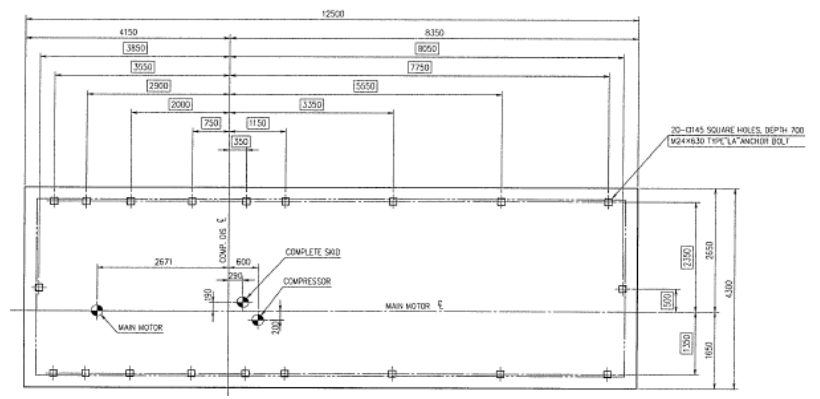

(a)

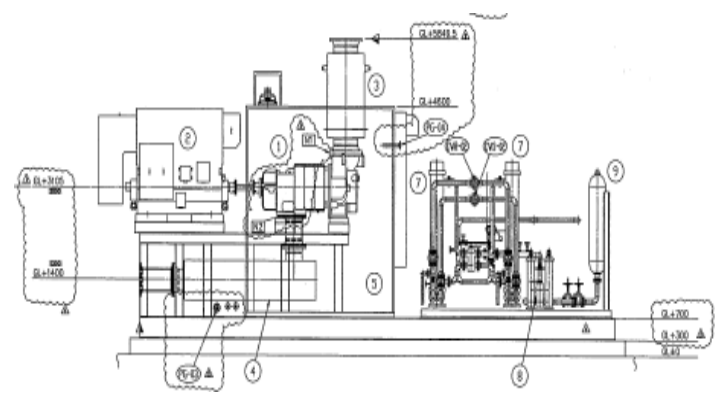

(b)

Source : Data in research, 2020

\section{Structure Data}

This machine is supported by a table top type machine foundation which is considered rigid while the portal structure specifications are as follows:

- Column dimensions 1(C1)

$$
\begin{aligned}
& : 1000 \mathrm{~mm} \times 1700 \mathrm{~mm} \\
& : 1200 \mathrm{~mm} \times 1700 \mathrm{~mm}
\end{aligned}
$$

- Column dimensions 2(C2)

- Column dimensions

- Beam dimensions

: $6000 \mathrm{~mm}$

- Plate dimensions

: $1300 \mathrm{~mm} \times 1600 \mathrm{~mm}$

- Plate thickness

: $15500 \mathrm{~mm} \times 7300 \mathrm{~mm}$

- Concrete Quality

$$
: 1000 \mathrm{~mm}
$$

: Fc 50

Figure 3. Portal Structure for Machines, a) Front View, b) Top View

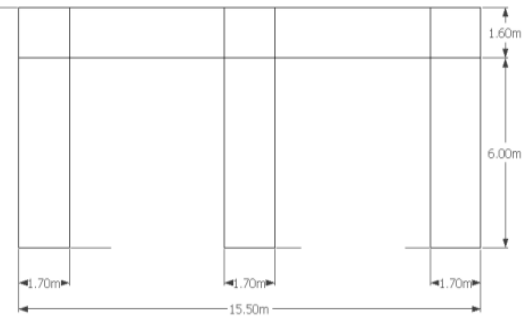

(a) 
Volume 03 Number 02 Maret 2020

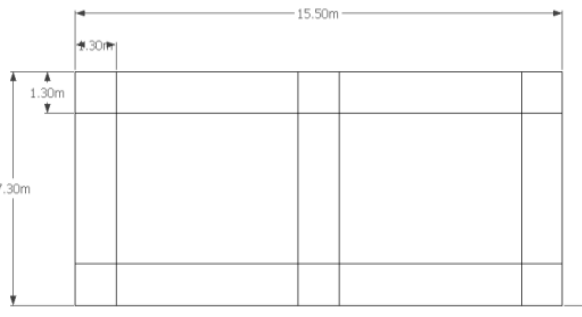

(b)

Source : Data in research, 2020

\section{Free Vibration Analysis}

\section{RESULT AND DISCUSSION}

Modal analysis is an analysis of internal forces or free vibration analysis without excitation of dynamic forces from outside when $\mathrm{p}(\mathrm{t})=0$. Modal analysis is carried out to obtain the natural frequency and initial vibration model of the building structure to determine whether there is a natural frequency value of the structure that is close to or equal to the machine frequency values.

If the engine frequency (operating frequency, $\omega$ ) is smaller than natural natural frequency $(\omega n) \omega / \omega n<0,8$ and the engine frequency is greater than natural frequency $\omega / \omega n>1,2$ then the structure can be said does not resonance (O'Neil.1979). When modal analysis working, the structure receives free vibrations. Free vibrations are vibrations that occur when there is no external vibration applied to the structure and the structure is considered to has no damping.

Table 2. Machine Frequency Against Natural Frequency Structure

\begin{tabular}{cllll}
\hline Mode & F Machine & F Structure & Result & Explanation \\
\hline 1 & 49.1667 & 17.82 & 0.36 & does not resonate \\
2 & 49.1667 & 24.45 & 0.49 & does not resonate \\
3 & 49.1667 & 26.78 & 0.54 & does not resonate \\
4 & 49.1667 & 106.41 & 2.16 & does not resonate \\
5 & 49.1667 & 121.02 & 2.46 & does not resonate \\
6 & 49.1667 & 148.06 & 3.01 & does not resonate \\
7 & 49.1667 & 204.41 & 4.15 & does not resonate \\
8 & 49.1667 & 207.33 & 4.21 & does not resonate \\
9 & 49.1667 & 225.28 & 4.58 & does not resonate \\
10 & 49.1667 & 242.35 & 4.92 & does not resonate \\
\hline
\end{tabular}

Source : Data in research, 2020

\section{Force Vibration Analysis}

Force vibration analysis is a force analysis which is influenced by dynamic force excitation at a certain time. Each engine creates a different force based on the type of engine driver. A reciprocating engine that is driven by a piston, gives rise two function of force and one function of the moment by the function of time. In this research, the dynamic load used is the load of the reciprocating compressor machine that is operating 
Volume 03 Number 02 Maret 2020

at a certain time, this analysis is needed to determine the amplitude of displacement, speed, and acceleration of the structure.

a) Structure Displacement

Displacement is the distance of one node from beams, columns, plates, etc. that move from the original location. The movement originates from deflecting rays, vibrations from moving objects, friction and so on. Displacement on the structure is shown in units of distance and rotation. Maximum displacement occurs in element 126 with $z$ directional displacement values of $-8,9 \times 10^{-5} \mathrm{~m} / 0,89 \mathrm{~mm}$.

Figure 5. Displacement in the Portal Structure

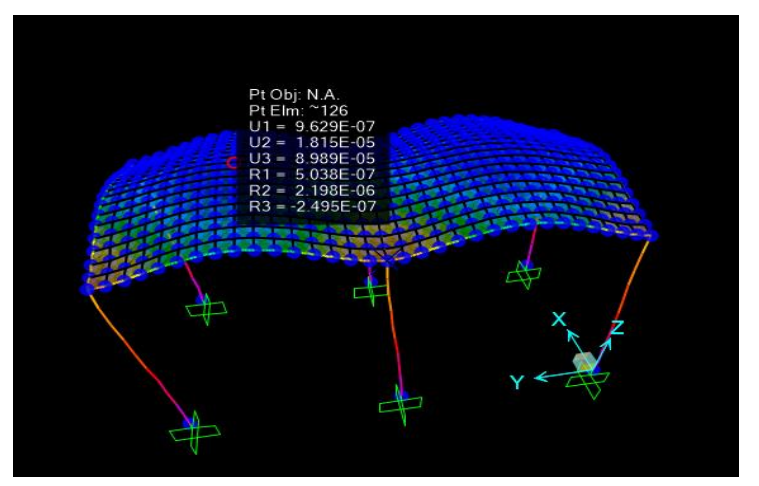

Source : Data in research, 2020

displacement / deflection in the portal structure occurs due to vibrations from the operating machine. In this research, the compressor engine discussed has a frequency of $49.16 \mathrm{~Hz}$. The limit of the structural displacement amplitude used in this study is based on ISO-4866-2010 after the portal structure is running, the results are obtained.

Table 5. Criteria for Acceptance of Displacement

\begin{tabular}{llll}
\hline Joint & Displacement $(\mathrm{mm})$ & $\begin{array}{l}\text { Acceptance } \\
\text { Criteria }(\mathrm{mm})\end{array}$ & Explaination \\
\hline 79 & 0,89 & $0,7-1,12$ & Zone C \\
\hline \multicolumn{4}{c}{ Source : Data in research, 2020 }
\end{tabular}

After run the analysis, it is found that the portal structure is included in zone C, which means that the machine is not safe if it is used for a long time continuously because it can damage the portal structure.

b) Velocity on Sctructure

Velocity or speed is a quantity that shows how far the displacement per unit distance. The speed of vibration in the structure needs to be considered because the faster the vibration from the machine that is transferred to the structure will make the structure's speed higher which will make the machine and also the quality of the product being worked on by the machine can be damaged.

The vibration velocity location reviewed is at the center of the portal structure with the assumption that the machine works for 5 seconds. After modeling the structure on running, we get transient speed (temporary) and steady state speed (balanced) direction $\mathrm{x}, \mathrm{y}, \mathrm{z}$ equal to.

\section{Table 6. Speed on Structure}

Direction Transient $\left(\mathrm{mm} / \mathrm{s}^{2}\right) \quad$ Steady State $\left(\mathrm{mm} / \mathrm{s}^{2}\right)$


Volume 03 Number 02 Maret 2020

\begin{tabular}{ccc}
\hline$X$ & 0,057 & 0,018 \\
$Y$ & 2,62 & 0,92 \\
$Z$ & 22,7 & 19,3 \\
\hline
\end{tabular}

Figure 6. Velocity X Direction on Portal Structure

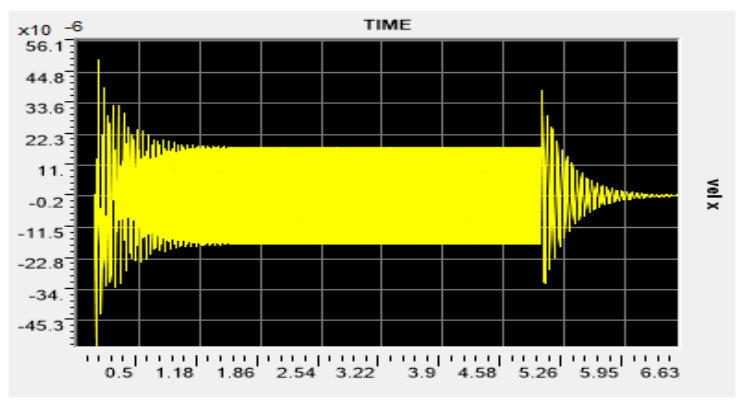

Source : Data in research, 2020

Figure 7. Velocity Y Direction on Portal Structure

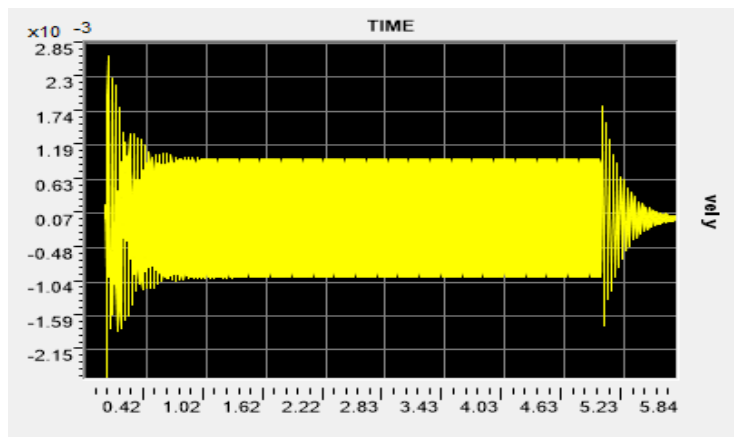

Source : Data in research, 2020

Figure 8. Velocity Z Direction on Portal Structure

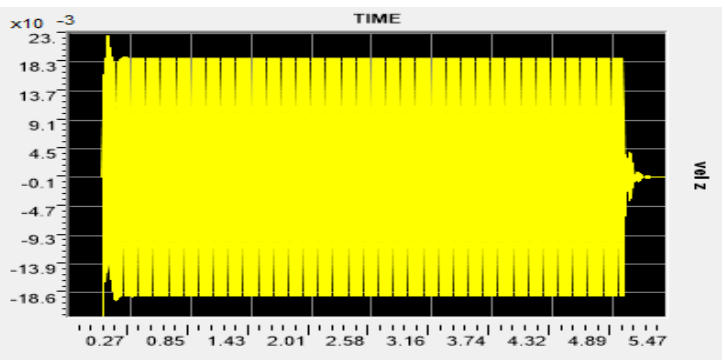

Source : Data in research, 2020

The vibration from the machine that operates has the speed and speed received by the floor structure needs to be noted in its limits so that human comfort and safety of objects around the machine can be maintained. The amplitude limit of the structural speed used in this study is based on ISO-10816-6 and the speed considered is at the center of the portal structure.

Table 7. Speed Acceptance Criteria

Speed $(\mathrm{mm} / \mathrm{s}) \quad$ Acceptance Criteria $(\mathrm{mm} / \mathrm{s})$ Explanation


Volume 03 Number 02 Maret 2020

\begin{tabular}{ccc}
\hline 22,7 & $4,6-28,2$ & Zone B \\
\hline
\end{tabular}

Source : Data in research, 2020

c) Acceleration of The Structure

Acceleration is the addition / change of speed of a force that moves in a certain time unit. To know the comfort of the portal structure to humans, it is necessary to know the acceleration produced by the portal structure due to machine vibrations. The location of the vibration acceleration reviewed is at the center of the portal structure with the assumption that the machine works for 5 seconds. After modeling the structure on running, the transient acceleration (temporary) and steady state (balanced) direction $x, y$, and $z$ are obtained.

Table 8. Acceleration on Structure

\begin{tabular}{|c|c|c|}
\hline Direction & Transient $\left(\mathrm{m} / \mathrm{s}^{2}\right)$ & Steady State $\left(\mathrm{m} / \mathrm{s}^{2}\right)$ \\
\hline $\mathrm{X}$ & $9,9 \times 10^{-3}$ & $4,51 \times 10^{-3}$ \\
\hline $\mathrm{Y}$ & 0,63 & 0,33 \\
\hline $\mathrm{Z}$ & 9,73 & 4,54 \\
\hline
\end{tabular}

Source : Data in research, 2020

Figure 9. Z Direction Acceleration in Portal Structure

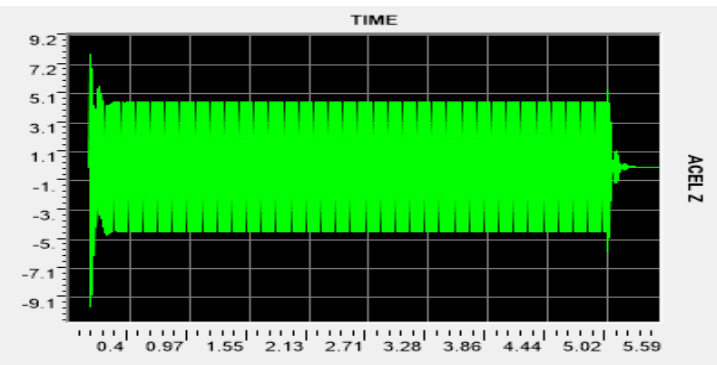

Source : Data in research, 2020

Figure 10. Y Direction Acceleration in Portal Structure

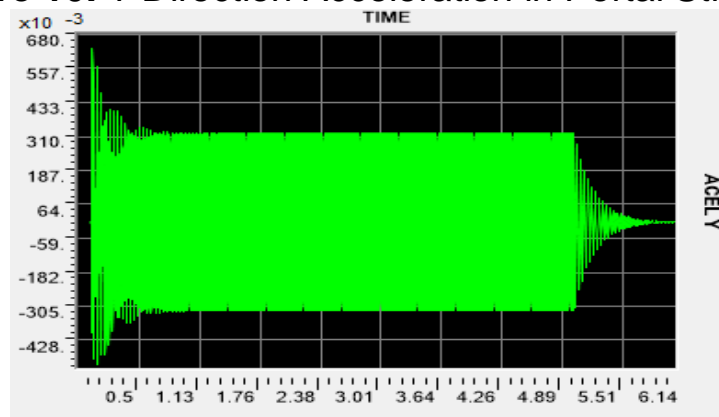

Source : Data in research, 2020

Figure 11. X Direction Acceleration in Portal Structure 
Volume 03 Number 02 Maret 2020

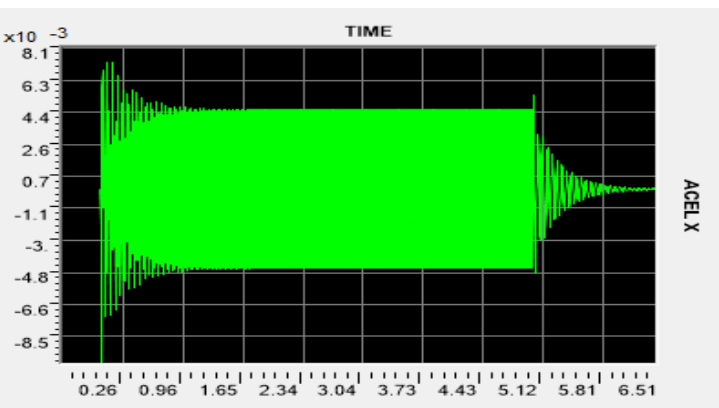

Source : Data in research, 2020

Machines that operate within a certain period of time have increased speed, this increase in speed is called acceleration. Based on PMKRI (Regulation of the Minister of Health of the Republic of Indonesia) No. 70 of 2016 taking into account the acceleration received is at the center of the portal structure. The acceleration received by the structure needs to be considered to avoid the occurrence of Whole Body Vibration (WBV) and Hand Transmitted Vibration (HTA).

The reciprocating machine in this study did not come into direct contact with the hands of the workers so that it only considered the effects of the Whole Body Vibration (WBV) experienced by the workers. The acceleration reviewed is steady state acceleration because the greater vibration is received by humans while transient vibration occurs very quickly and is fully accepted by the structure.

Table 9. Criteria for Acceptance of Acceleration

\begin{tabular}{ccccc}
\hline Direction & $\begin{array}{c}\text { Acceleration } \\
\left(\mathrm{m} / \mathrm{s}^{2}\right)\end{array}$ & $\begin{array}{c}\text { Period } \\
(\mathrm{s})\end{array}$ & $\begin{array}{c}\text { Acceptance Criteria } \\
\left(\mathrm{m} / \mathrm{s}^{2}\right)\end{array}$ & Explanation \\
\hline $\mathrm{X}$ & $9,9 \times 10^{-3}$ & 60 & 50 & SAFE \\
$\mathrm{Y}$ & 0,63 & 60 & 50 & SAFE \\
$\mathrm{Z}$ & 9,73 & 60 & 18 & SAFE \\
\hline \multicolumn{5}{c}{ Source : Data in research, 2020}
\end{tabular}

\section{CONCLUSION}

This study discusses the problem of vibrations in the foundation structure of table top engines or commonly called portal structures due to vibration of reciprocating compressor machines that work. Dynamic load in the form of machine activity when operating states that the portal structure is still eligible to receive these vibrations. The analysis results obtained from the structural model explain that the conclusions of this big assignment are:

1. The natural frequency of the structure has a difference that is very far from the natural frequency of the applied machine that is $(f=49.67 \mathrm{~Hz})$ so that the structure can be obtained safe from resonance.

2. The natural frequency of the structure needs to pay attention to the amplitude of the displacement, velocity, and acceleration of vibrations received by the structure to ensure that the structure is completely safe for the machine itself, the structure, and the humans around the machine.

3. The magnitude of the vertical displacement amplitude due to vibration when the engine is operating at $0.89 \mathrm{~mm}$, the number is fairly safe so that the incoming structure $c$, which means the machine is not safe if used for long periods continuously because it can damage the portal structure. 
Volume 03 Number 02 Maret 2020

4. The highest structure speed when the steady state (balanced) vertical direction is $22.7 \mathrm{~mm} / \mathrm{s}$, based on that number the structure is in category b so that the machine can work in the long run on the structure without damaging the engine and the product produced.

\section{REFERENCES}

Abdurrozak, M. R., Purnomo, A., \& Purwanto, E. (2017). Evaluasi Pondasi Mesin dengan Tiang Pancang Akibat Getaran Peciprocating Engine (Studi Kasus PLTU UBOH 3 Banten). Simposium II UNIID 2017, 2(1), 407-416.

Ahmad S.Farid (1021052) (2013) Studi Pengaruh Berat Pondasi Mesin Tipe Blok Terhadap Respon Tanah.

Ambada, Ari Dwi (2013) Perancangan Struktur Pondasi Mesin Blower pada Pabrik Pengolahan Emas Martabe di Tapanuli Selatan, Sumatra Utara.

Ayuddin, Frice L. Desei. (2017). Analisis Kekuatan Struktur Pondasi untuk Dudukan Mesin Turbin

Bachmann, H., Ammann, W. J., Deischl, F., Eisenmann, J., Floegl, I., Hirsch, G. H.,\& Nussbaumer, H. (2012). Vibration problems in structures: practical guidelines. Birkhäuser.

Bhandari, P. K., \& Sengupta, A. (2014). Dynamic analysis of machine foundation. International Journal of Innovative Research in Science, Engineering and Technology, 3, 169-176.

Bhatia, K. G. (2008). Foundations for industrial machines and earthquake effects. ISET Journal of Earthquake Technology, Paper, (495), 1-2.

Budio Sugeng, P. (2010). Buku Ajar Dinamika Struktur.

Febrianto. (2015). Perencanaan dan Pelaksanaan Pondasi Mesin - Mesin Generator PT.EPFM.

Pakpahan, B.T.S. (2013). Analisis Pengaruh Renovasi Struktur Pabrik Terhadap Respon Dinamik.

Patel, U., Mangukiya, S., Miyani, A., Patel, H., Vora, S., \& Sevelia, J. (2015). Dynamic analysis of foundation supporting rotary machine. Int. J. Eng. Res. Appl, 5(8), 3445.

[PMK] Peraturan Menteri Kesehatan Republik Indonesia no 70 Tahun 2016 Tentang Standar Kesehatan Lingkungan Kerja Industri

Setyono, E., \& Amudi, A. (2016). Analisis Perencanaan Pondasi Dinamis Untuk Mendukung Mesin Turbin Pada Pabrik Gula Cukir Jombang. Media Teknik Sipil, 13(2).

Srinivasulu, P., \& Vaidyanathan, C. V. (1976). Handbook of machine foundations. Tata McGraw-Hill Education.

Suresh, A., O'Neill, M., \& Pincus, G. (1979). Design of Structures and Foundations for Vibrating Machines.

Tjerita, A. K. N. (2018). Perancangan Pondasi Mesin

Xiao, S., Liu, S., Cheng, S., Xue, X., Song, M., \& Sun, X. (2017). Dynamic analysis of reciprocating compressor with clearance and subsidence. Journal of Vibroengineering, 19(7), 5061-5085. 